\title{
EL LENGUAJE EN LA ESTÉTICA DE CROCE
}

Benedetto Croce abandonó las minucias y anécdotas que le habían absorbido en los años juveniles, y se enfrentó a la vida del espíritu, con la disertación acerca de la naturaleza de la historia (1893) y con el opúsculo acerca de la crítica literaria (1894), disertación y opúsculo que no sólo aclaraban al joven erudito los métodos de la investigación histórica y literaria, sino que encaraban sistemáticamente los problemas que serían capitales en la actividad futura del filósofo. Esos dos escritos abrieron el camino que, en 19oo, llevó a las Tesi fondamentali di un'estetica come scienza dell' espressione e linguistica generale, disertación académica que, en el año siguiente, quedó completamente rehecha y fundida en la primera edición de la Estetica (salida a la luz, fecha gloriosa, en abril de 1902).

Las Tesi fondamentali no tardaron en parecerle a Croce un tratado "árido y abstruso". Pero en él presentaba ya su doctrina estética, inserta en un esbozo de toda la filosofía del espíritu, sobre cuyos problemas - los problemas que han fatigado a través de los siglos a los "filósofos clásicos"- se concentraba, como dice el precioso Contributo alla critica di me stesso, una inteligencia pronta e infalible, la que se obtiene no simplemente con la lectura de los grandes pensadores, sino "con el repetir en sí mismo, bajo el estímulo de la vida", el drama mental de esos hombres.

Lo habían acompañado en la investigación sobre el arte como pura forma espontánea y fantástica las páginas de De Sanctis, meditadas desde los años de liceo. Pero entre 1892 y comienzos de 1893 leyó y releyó, vigilante y tenaz, al Vico de la Scienza nuova. Se multiplican las referencias a Vico en el opúsculo sobre la crítica literaria, donde una nota advierte que ningún otro tratadista italiano de filosofía del arte tiene "las profundas concepciones sobre la naturaleza de la poesía y de la fantasía que están esparcidas en la Scienza nuova". Y esta obra es la levadura que fermenta en las Tesi fondamentali, las cuales constituyen la sección teórica de la. Estetica come scienza dell'espressione e linguistica generale; de su parte histórica se extrajeron previamente algunos capítulos para un artículo publicado en la revista napolitana Flegrea en abril de 1901 e intitulado "Giambattista Vico, primo scopritore della scienza estetica". 
Reivindicación legítima ésa de la originalidad de Vico. En su obra monumental, que encierra una nueva visión de la realidad toda, nace efectivamente la Filosofía como ciencia del espíritu (contra las anteriores concepciones de contenido teológico, físico y metafísico) y, al mismo tiempo, nace la Estética. Nace en cuanto que la poesía se ve y concibe (contra las negaciones del racionalismo y anti-lirismo cartesiano) en su naturaleza de actividad teorética fundamental y eterna del espíritu, y es determinada como la primera forma del conocer, la cual representa el momento en que el hombre "advierte con ánimo perturbado y conmovido" -vale decir, representa el conocimiento fantástico e intuitivo, alógico y extra-racional-, y se identifica con la época histórica de la barbarie. De ese modo Vico subvierte la concepción de la poesía como refinada y florida ficción que encubre verdad y sabiduría, como medio de distracción y placer, como inútil ejercicio de ingenio.

Pero "casi más milagroso" que la misma nueva y revolucionaria concepción de la poesía parecía a Croce -y lo es, en efecto- el hecho de que Vico haya descubierto la auténtica cualidad del lenguaje, señalando sus verdaderos orígenes "en los principios de la poesía", esto es, el hecho de que haya afirmado el espontáneo y perenne origen fantástico del lenguaje, y de que, "implícitamente", tendiera a identificar lenguaje y poesía. Decía Vico:

La guisa del nascimento o sia la natura delle lingue troppo ci ha costo di aspra meditazione; né, dal Cratilo di Platone incominciando, del quale in altra opera filosofica [en el De antiquissima italorum sapientia] ci siam con error dilettati, insino a Wolfango Lazio, Giulio Cesare Scaligero, Francesco Sanzio ed altri ne potemmo in appresso mai soddisfare l'intendimento. Perché vi voleva una fatiga tanto spiacente, molesta $e$ grave, quanto ella era di spogliare la nostra natura per entrare in quella de' primi uomini, muti affatto d'ogni favella, de' quali provennero le lingue delle gentili nazioni. Ma, siccome noi, forse entratici, scuoprimmo altri principii della poesia, e truovammo le prime nazioni essere state di poeti, in questi stessi principii ritruovammo le vere origini delle lingue.

Así, la Scienza nuova subvierte también lo que se había lucubrado acerca del lenguaje, juzgado unas veces como de origen divino, otras como fruto de operación voluntaria, otras como obra de la lógica. Aspira sobre todo a acabar con este último error ("colosal error" para Croce), que tanto ha durado y que resurge una y otra vez, de la supuesta relación entre lengua y pensamiento, del paralelismo lógico-gramatical. A propósito de la oposición entre "sabiduría vulgar" o poética y "sabiduría recóndita" o filosófica, entre conocimiento fantástico (intuitivo, pasional, corpolento) y conocimiento 
conceptual (reflexivo, desapasionado, abstractivo), entre lengua y pensamiento, en suma, leemos en la primera Scienza nuova:

Gli studi della metafisica e della poesia sono naturalmente opposti tra loro. Perché quella purga la mente dai pregiudizi della fanciullezza, questa tutta ve la immerge e rovescia dentro; quella resiste al giudizio dei sensi, questa ne fa principale sua regola; quella infievolisce la fantasia, questa la richiede robusta; quella ne fa accorti di non fare dello spirito corpo, questa non di altro si diletta che di dare corpo allo spirito; onde $i$ pensieri di quella sono tutti astratti, $i$ concetti di questa allora sono piu belli quando si formano più corpolenti.

Las ideas esenciales de Vico, renovadoras de la filosofía del lenguaje, fueron proseguidas, en Alemania, por J. G. Hamann, J. G. Herder, W. von Humboldt. Este último definió la lengua "no como obra, sino como actividad"; sintió que la verdadera lengua consistía "en el acto mismo de producirla mediante las palabras entrelazadas en discurso", y que el despedazamiento en palabras y reglas era "una tarea muerta de análisis científico". Y aunque pensó que, en sustancia, la lengua colectiva no venía a ser sino la suma de las creaciones individuales, reconoció que su definición de la lengua, si se procede rigurosamente, "en el sentido verdadero y profundo", no se aplica a otra cosa que a la libre creación individual del espíritu. Pero la ciencia del lenguaje, que por entonces se estaba constituyendo, se dejó influir (o mejor dicho, configurar) por el evolucionismo darwinista más bien que por el idealismo de Humboldt; y, siguiendo a August Schleicher, concibió las lenguas como organismos naturales, que nacen, crecen, se desarrollan y mueren "según procesos internos, ajenos a la voluntad de los hablantes". Concepción explícitamente naturalista y determinista. Y a pesar de que, en el tiempo de los "neogramáticos", se quiso en teoría reconocer la lengua como "producto del espíritu colectivo de los grupos lingüísticos" y conceder un lugar a la iniciativa de los individuos, los lingüistas permanecieron fieles, en realidad, al principio de la evolución mecánica y regular. Vino a continuación la escuela sociológica de Ferdinand de Saussure (cuyo Cours de linguistique générale, publicado póstumamente en 1916, es el resultado más conspicuo a que haya llegado el positivismo en la ciencia del lenguaje) y separó con un tajo resuelto la lengua individual de la común, distinguió la parole (en evolución ininterrumpida, que reproduce los movimientos del alma individual) de la langue (sistema fijo y harmónico de signos, y norma a que se sujeta la comunidad de los hablantes), y en la norma, en el sistema de signos, en el funcionamiento del sistema, puso el objeto primero y esencial de todo estudio lingüístico. Así, el fiel seguidor de Saussure, el lógico impertérrito Viggo Bröndal, decía que "sólo estudiando los signos separados, y por lo tanto las palabras 
independientemente de la frase, y su posición en el sistema, nos es dado captar la lengua en su totalidad". Parece lícito, después de esto, concluir que, con Saussure y sus continuadores (Trubetzkoj, Bröndal, Hjelmslev ...) se nos orienta de tal manera -como entre otros ha puesto de relieve el llorado Amado Alonso- hacia lo que es extrapersonal y automático, que ya no se vislumbra siquiera la naturaleza de canto y poesía, la calidad humana y espiritual que es propia del lenguaje, ni el continuum de la expresión en que ese lenguaje se manifiesta.

Benedetto Croce, al reaccionar, hace más de cincuenta años, contra el naturalismo y positivismo entonces dominantes, y en su ansia de lo concreto, afirmó que "el lenguaje es un acto espiritual y creador"; y retomando y harmonizando en un pensamiento coherente y sistemático, repensando y prosiguiendo intuiciones anteriores dispersas, en especial las genialísimas de Vico, instó sobre el particular problema que urgía resolver, o sea, a qué peculiar forma de espiritualidad se deba referir el acto linguístico. Sus meditaciones y estudios lo llevaron a la conclusión, formulada ya en las Tesi fondamentali, de que el acto del lenguaje (son sus palabras precisas) "no es ya la expresión del pensamiento y de la logicidad, sino de la fantasía, esto es, de la pasión elevada y transfigurada en imagen, y por lo tanto idéntico a la actividad de la poesía, sinónimo el uno de la otra".

El lenguaje, considerado en toda su desnudez y pureza, en su genuina esencia, debe entenderse como expresión fantástica, musical y poética. Pero esa misma naturaleza la conserva cuando se hace signo de pensamientos y conceptos, o es expresión práctica, o síntoma de conmociones; y se refleja en aquello que, aun en el lenguaje de la prosa, es metáfora, harmonía de sonidos, música del período.

Ahora bien, asentado el principio de que la fantasía, la cual "crea sus imágenes y canta como poesía", es el lenguaje mismo, cabía pasar lógicamente a la identificación del lenguaje poético con cualquier otro lenguaje, de la música, de la pintura, de la escultura, de la arquitectura, y cabía pasar a la identificación de la Filosofía del lenguaje con la de la poesía o del arte en general: esto es, de la Lingüística con la Estética.

Por esta última identificación, es evidente que las expresiones del lenguaje (si no se pueden interpretar, gustar y juzgar más que como poesía, y por lo tanto "en el nexo inseparable de contenido y forma de la sola síntesis estética en que tienen su realidad") deben pasar a ser objeto de estudio de los críticos e historiadores de la poesía y de la literatura, o de los lingüistas que sean críticos.

Otras deducciones se han desprendido legítimamente de la doctrina crociana. Se ha eliminado el viejo problema del origen del lenguaje; el lenguaje no es una institución formada en un preciso mo- 
mento histórico, sino una categoría, o sea un grado del espíritu, como lo es, por ejemplo, la moral. Se han descartado las doctrinas que explicaban el lenguaje por la onomatopeya, por la interjección, por los signos convencionales. Se han abandonado las definiciones intelectualistas de las partes del discurso (exploradas según el esquema de la lógica tradicional y formal de Aristóteles, o bien en harmonía con la lógica general y pura, por ejemplo, de Husserl) y las distinciones entre palabra propia y palabra figurada, etc., como también se han abandonado las especulaciones, hechas en un crudo clima naturalista y positivista, de las "leyes fonéticas", a cuyo imperio más o menos absoluto se plegaría la evolución del lenguaje.

A una pregunta que surge espontáneamente y vuelve con insistencia, respondió varias veces Croce con determinaciones más y más ceñidas. Puesto aparte el juicio sobre las expresiones del lenguaje, que, como se ha dicho, es juicio estético coincidente con el juicio sobre las obras de arte, ¿cuál será la naturaleza del estudio de la lengua que es objeto de los lingüistas como tales, de los lingüistas puros, que se interesan en los sonidos y las formas, en los significados y los nexos sintácticos, en los vocablos y las etimologías? Es, para Croce, un estudio extraestético: no el del lenguaje como producción, susceptible de contemplarse en su momento de expresividad; no la historia de la poesía; sino una "disciplina histórica" que estudia las palabras, sus mutaciones de forma y de sentido, su trabazón en nexos y períodos, "en relación con el desarrollo del pensamiento, del sentir, de la costumbre moral, y, en suma, de la historia toda, a la cual pertenece el habla". En pocas palabras, "historia del lenguaje resuelta en historia estética", por un parte, y, por otra, "historia de las palabras resuelta en historia social".

De la aceptada necesidad de indagar la lengua "en función del espíritu del hablante" y de la convicción de que, en este examen, como Croce ha comentado, "el lenguaje de los escritores originales es por lo menos tan importante como las anónimas creaciones lingüísticas que a cada instante se operan y divulgan (únicas en que se hacía consistir, en un tiempo, el trabajo de los lingüistas)", ha tomado arranque, a principios de nuestro siglo, la Filología y Lingüística idealista de Karl Vossler y de sus numerosos y entusiastas discípulos y seguidores (no sólo alemanes). Insigne entre todos es Leo Spitzer, cuyos ensayos de estilística, y sobre todo los más recientes, publicados (nótese bien) con el título de Linguistics and literary history, representan una novedad espléndida, como también las investigaciones de Mario Fubini (por ejemplo el volumen Stile e umanità di Giambattista Vico) y las de Amado Alonso (cito sólo Poesia y estilo de Pablo Neruda), Dámaso Alonso (cito sólo Poesia española), Erich 
Auerbach (Mimesis) y Helmut Hatzfeld ("Don Quijote" als Wortkunstwerk), para reducir al mínimo esta enumeración.

La Estética de Croce ha dado también la mano -quiero decir apoyo y confirmación, luz y vigor persuasivo- a la obra y a la meditación del más genial de los lingüistas, Hugo Schuchardt, y de poderosos reformadores como Jules Gilliéron. No puedo detenerme ahora en particulares, pero recojo por lo menos el testimonio del lingüista norteamericano Edward Sapir en el prólogo de su excelente Language: "Entre los escritores contemporáneos que tienen alguna influencia sobre el pensamiento ilustrado, Croce es uno de los poquísimos que han podido captar la significación fundamental del lenguaje. Ha subrayado su estrecho parentesco con el problema del arte. Debo mucho a su perspicacia”.

El pensamiento de Benedetto Croce no ha cesado de obrar. Y podemos esperar, o augurar, que su influencia aumente en eficacia, ahora que en la lingüística se está volviendo a un logicismo más rígido, abstracto y abstractivo que aquel al cual se opuso ya la Scienza nuova de Vico.

Alfredo Schiaffini

Roma, Università. 